\title{
Autoficção e experiência em O pai da menina morta, de Tiago Ferro
}

\author{
Autofiction and experience in O pai da menina morta, by Tiago Ferro \\ Autoficción y experiência em O pai da menina morta, de Tiago Ferro
}

Ricardo Augusto de Lima*

\begin{abstract}
Resumo
Com base nos conceitos de "experiência do fora" de Maurice Blanchot e "experiência interior" de Georges Bataille, neste artigo analiso o deslocamento do sujeito para o fora no romance $O$ pai da menina morta, de Tiago Ferro. Embora Blanchot recuse o Eu que fala na obra literária e seu discurso pessoal, proponho, ainda assim, como chave de leitura, a autoficção, que se concretiza no texto não como recurso estilístico e crítico (como se observa com frequência na literatura contemporânea), mas enquanto deslocamento do eu empírico do escritor para outro, dando origem a um duplo que não mais remete a um real precedente e tampouco constitui uma cópia, cujo sentido só se concretiza com o leitor e sua experiência pessoal que preencherá os espaços vazios da narrativa. Objetivo demonstrar, portanto, como as duas leituras não são contraditórias, mas complementares na medida em que o centro da narrativa está no deslocamento, depois da experiência de perda vivenciada pelo personagem anônimo e sua necessidade de se ajustar diante da ausência. A partir de sua própria experiência, Ferro cria um romance lírico e fragmentado que, nascido da morte, busca pelo que ainda resta de vivo nesse sujeito que não quer, e nem pode, ser chamado de Eu.
\end{abstract}

Palavras-chave: experiência do fora, experiência literária, Tiago Ferro, autoficção.

\begin{abstract}
Based on the concepts of "experience of the outside" by Maurice Blanchot and "interior experience" by George Bataille, in this paper I analyze the displacement of the subject to the outside in the novel O pai da menina morta, by Tiago Ferro. Although Blanchot rejects the literary Self of the work and its personal speech, I propose, autofiction as a way of reading Ferro's work. Autofiction materializes in the text not as a stylistic and critical device (as is often the case in contemporary literature), but as a displacement of the author's empirical self to the other, engendering a double that no longer refers to a real precedent, neither consists in a copy, whose meaning is only effective with the reader and his personal experience that will fill in the blank spaces of the narrative. Therefore, I intend to demonstrate how both readings are not contradictory but complementary once the narrative core is displaced, after the loss experienced by the anonymous character and his need to adjust against absence. From his own experience, Ferro creates a lyrical and fragmented novel that, born from death, looks for what is still alive in this subject who neither wants to, nor
\end{abstract}

\begin{abstract}
Resumen
Con base en los conceptos de "experiencia del afuera" de Maurice Blanchot y "experiencia interior" de Georges Bataille, analizo, en este artículo, el desplazamiento del sujeto hacia el exterior en la novela $O$ pai da menina morta [El padre de la chica muerta], de Tiago Ferro. Aunque Blanchot rechaza el Yo que habla en la obra literaria y su discurso personal, propongo, todavía, como clave de lectura, la autoficción, que se concreta en el texto no como un recurso estilístico y crítico (como se percibe a menudo en la literatura contemporánea), sino como el desplazamiento del yo empírico del escritor hacia el otro, dando origen a un doble que ya no remite a un real precedente y tampoco constituye una copia, cuyo sentido sólo se concretiza con el lector y su experiencia personal que llena los espacios vacíos de la narrativa. Mí objetivo es, por lo tanto, demonstrar cómo las dos lecturas no son contradictorias, sino complementarias en la medida en que el centro de la narrativa está en el desplazamiento, después de la experiencia de pérdida vivida por el personaje anónimo y de su necesidad de encontrarse ante la ausencia. A partir de su propia experiencia, Ferro crea una novela lírica y fragmentada que, nacida de la
\end{abstract}

\footnotetext{
* Doutor em Letras pela Universidade Estadual de Londrina (UEL), Londrina, PR, Brasil. (Dorcid.org/0000-0002-5026-6144. Email: ricardodalai@gmail.com.
} 
can, be called the Self.

Keywords: experience of the outside, literary experience, Tiago Ferro, autofiction. muerte, busca lo que aún queda de vivo en ese sujeto que no es, ni puede ser, llamado Yo.

Palabras clave: experiencia del afuera, experiencia literaria, Tiago Ferro, autoficción.

"Si mesmo" não é um sujeito que se isola do mundo, mas um lugar de comunicação, de fusão do sujeito e do objeto.

Georges Bataille

\section{Ontem}

O pai dirige enquanto o filho está no banco de trás do carro. Vez ou outra, esse pai olha para esse filho no banco de trás para verificar se está tudo bem. Depois, volta os olhos para a estrada e continua dirigindo. Às vezes a mãe fala alguma coisa, às vezes o pai responde. O menino no banco de trás pergunta se está chegando, e entre respostas e perguntas, o pai olha para o filho no banco de trás do carro pelo retrovisor para verificar se está realmente tudo bem.

Um dia, há muito tempo, escrevi um conto sobre um pai que olhava para o filho no banco de trás do carro pelo retrovisor enquanto dirigia. $O$ filho, não me lembro por que nem de que, morria. A imagem que principiava o conto era esta: a do pai olhando para o banco de trás pelo retrovisor enquanto dirigia, e no lugar em que sempre via o filho dormindo ou olhando a paisagem que passava, não via nada. Era essa a chave do conto, e é isso que me interessa até hoje nessa narrativa que se perdeu: esse nada deixado pela morte do filho no banco de trás do carro.

Que nome tem isso? Que nome ele tem? Que nome recebe um pai que já não é pai? Filho/a sem pai continua sendo, é órfã/o: filha/o cujos pais morreram. E pai sem prole? Que palavra tem? Nenhuma no dicionário. Nada. Como um grande abismo, um grande breu. Um silêncio só.

\section{Benjamin}

Nos conhecidos ensaios "Experiência e pobreza", de 1933, e "O narrador", de 1939, Walter Benjamin mostra como vivenciamos um declínio da experiência, que é, por sua vez, apenas parte da condição humana no século $X X$, quando os indivíduos se tornaram " $[\mathrm{m}]$ ais pobres de experiências comunicáveis, e não mais ricos" (Benjamin, 1996, p. 115). Ao perceber que os sobreviventes da guerra voltavam mudos das trincheiras, Benjamin infere que a experiência de guerra não pode ser assimilada por palavras, e uma outra esfera do amplo conceito de experiência se faz necessária, pois "[é] como se estivéssemos privados de uma faculdade que nos parecia segura e inalienável: a faculdade de intercambiar experiências" (Benjamin, 1996, p. 198). Os sujeitos são/estão, sobretudo, cansados e nada mais lhes resta além de sonhar, pois "ao cansaço segue-se o sonho, e não é raro que o sonho compense a tristeza e o desânimo do dia, realizando a existência inteiramente simples e absolutamente grandiosa que não pode ser realizada durante o dia, por falta de forças" (Benjamin, 1996, p. 118).

Vive-se apenas, e nada se experimenta. Coberto de futuro, o sujeito moderno caminha na vida sem laços com o passado, atropelado por um presente ansioso de consumo, não de experiências. Esses sujeitos, de fato, só experimentam o absurdo e a brutalidade da vida, dirá Benjamin, que denuncia a crise do narrador como consequência direta desse declínio da experiência, diagnóstico para o qual o pensador reúne duas reflexões: uma sobre o desenvolvimento das formas produtivas e da técnica e outra sobre a memória traumática, a experiência do trauma, do choque, e sua assimilação pela linguagem e qualquer outra esfera do simbólico. A vida desse sujeito fragmentado e apático "não contém quase nada que seja ainda traduzível em experiência", como escreveu mais recentemente Giorgio Agamben (2005, p. 22). "O homem moderno", diz ele, "volta para a casa à noitinha extenuado por 
uma mixórdia de eventos - divertidos ou maçantes, banais ou insólitos, agradáveis ou atrozes - entretanto nenhum deles se tornou experiência".

Neste contexto, que se estende desértico até nossa contemporaneidade, (re)pensar as experiências possíveis por meio da Literatura se torna não apenas um dever acadêmico, mas também humano. É tentar compreender que, ao menos em um campo de relações, existem possibilidades além desta trágica realidade nossa, nossa frágil condição humana.

\section{Blanchot}

Maurice Blanchot viveu, na prática, o desvanecimento do autor que me parece parte essencial de seu pensamento na medida em que alimenta o que o filósofo chamou de "o fora". Fundamentando-se na crise da representação iniciada no fim do século XIX para defender a rejeição do eu pessoal na escrita, Blanchot (2011, p. 331) afirma que "[a] palavra me dá o ser, mas ele me chegará privado de ser. Ela é a ausência desse ser, seu nada, o que resta dele quando perdeu o ser, isto é, o único fato que ele não é". Assim, na sua potência de negatividade, isto é, o poder que a linguagem tem de aniquilar o que nomeia, Blanchot mostra o vínculo entre morte, linguagem e experiência literária, uma vez que a literatura se torna espaço de liberdade e morte, de infinito e de ausência de mundo, do nada.

Voz despatriada, sem rosto, provinda do vazio, esse Ninguém está "condenado a falar sem repouso" e representa "algo que é verdadeiramente experimentado", "precisamente uma experiência vivida sob a ameaça do impessoal, a aproximação de uma fala neutra que fala sozinha, que atravessa aquele que a escuta, que é sem intimidade, exclui toda intimidade, e que não podemos fazer calar, pois é incessante, o interminável" (Blanchot, 2005, p. 312). Corpo neutro, embora corpo não seja, é apenas um murmúrio, um ruído. Um rumor que "espera a força escondido da fala que não é uma fala, doce hálito da eterna repetição" (Blanchot, 2005, p. 322). O silêncio entre o raio e o trovão.

Arrastado para o fora - antes uma prática que um conceito, fruto da busca de Blanchot pelo elemento que diferenciaria a linguagem literária da linguagem cotidiana - o autor é senão um exilado, sem posses e sem terras, entregado ao vazio e ao deserto; "ninguém, o lugar vazio e animado onde ressoa o apelo da obra" (Blanchot, 2005, p. 316). Ali ele não pode viver nem morrer. Ele não começa nem termina, "um ser sem ser" recoberto "por um Eu poroso e agonizante" (Blanchot, 2005, p. 312). Ele está sozinho: trata-se de uma solidão ontológica, ou seja, uma solidão do ser não subordinado ao ente.

Em oposição à ideia de que a literatura seria um meio de se chegar ao muito exterior e de nele se engajar, Blanchot defendia que a palavra literária é fundadora de sua própria realidade. Esta realidade tem como característica ser obscura, ambígua, desconhecida. O engajamento do escritor consistia menos em fazer a ponte entre literatura e realidade exterior do que em construir a própria realidade literária (Levy, 2011, p. 18-19).

Assim, a "linguagem da ficção" possibilita a experimentação de um evento real e pleno, pois trata-se de uma linguagem/realidade que se funda em movimento sempre metalinguístico, realizando-se a si própria, resultado do encaixe exato entre palavras e silêncios, entre o dito e o não dito. Entidade vazia, "a linguagem não parte do mundo, mas constitui seu próprio universo, cria sua própria realidade" (Levy, 2011, p. 20). Não representa, senão apresenta "o outro de todos os mundos", "uma experiência que, ilusória ou não, aparece como meio de descoberta e de um esforço, não para expressar o que sabemos, mas para sentir o que não sabemos" (Blanchot, 2011, p. 87). Importa-lhe delinear como a irrealidade da ficção promove uma experiência real, a própria experiência da realidade imaginária. Ali não existe verdade, sabemos. Tampouco mentiras. As palavras são entidades vazias: quando digo uma coisa, digo sempre outra coisa que não é o que eu queria dizer, e isso é recebido pelo outro como outra coisa ainda, permeada pelo pessoal da experiência de quem lê. Por isso, embora faça referência a este mundo, ou tentando explicálo, ou utilizando-o como base mimética, a literatura só pode expressar sua realidade de 
forma negativa, ou seja, pelo imaginário: que não é uma "estranha região situada além do mundo; é o próprio mundo, mas o mundo como conjunto, como o todo" (Blanchot, 2011, p. 325), mundo ideal e infinito e, por isso, um não mundo, que contrasta com este por ser finito e singular.

Lugar de negação do real, o artista é quem se perde nesse espaço sem lugar e, consequentemente, perde o mundo e a possibilidade de dizer $E u$. Ele fala de um Éden, de onde toda palavra soa original e fundadora. Não a voz, mas o ruído que a antecede. $\mathrm{O}$ rumor, o "ainda não". Como escreve Tatiana Salém Levy (2011, p. 32), "[c]olocar-se fora de si e fora do mundo é antes de mais nada inaugurar uma experiência em que as coisas não são ainda. Tudo se passa na literatura como se nada tivesse acontecido, como se tudo estivesse por acontecer". Daí a impossibilidade autobiográfica do eu empírico do autor coincidir com aquele outro da ficção, construído em espaço e tempo puros, que fala por meio de uma sombra gerada a partir da mortificação da experiência da escrita.

\section{A morte}

"Para o coração a vida é simples: ele bate enquanto puder. E então para". Essa é a frase que inicia A morte do pai, primeiro volume da saga detalhadamente autobiográfica Minha luta, do norueguês Karl Ove Knausgård (2015, p. 7). Como se percebe, de forma edipiana, Karl Ove começa com a morte de seu pai. "É um cenário desolador e estranho", escreve o narrador, "como uma fábrica que trabalhadores tivessem sido obrigados a evacuar às pressas" (Knausgård, 2015, p. 8).

Presença ambígua em nossa existência, “[a] morte dá origem à primeira pergunta - Por quê? - e mata todas as respostas" (Wood, 2017, p. 12). Como escreve Bataille (2016, p. 28-29), nela "[o] espírito se move num mundo estranho em que a angústia e o êxtase se combinam", originando uma experiência inefável e sem tradução: "O que caracteriza tal experiência, que não procede de uma revelação, em que nada tampouco se revela, senão o desconhecido, é que ela nunca traz nada de apaziguador". Esse saber de que fala Bataille não é senão estar consciente da finitude das coisas, é perguntar-se Por quê?, é a recusa em aceitar a morte. A busca de evitar, de alguma maneira, que ela seja o destino final. Quem sabe nela a consciência dança "pela aurora boreal. Livre. Jamais lembrando daquilo que um dia chamou de humano" (Ferro, 2018, p. 89).

"Para o coração a vida é simples: ele bate enquanto puder. E então para."

Essa é a epígrafe de O pai da menina morta, de Tiago Ferro.

V

"Não há nada mais triste do que a certidão de óbito de uma criança" (Ferro, 2018, p. 157), cito de cabeça uma das frases do último trecho do romance. Não se preocupe, não é um spoiler. Na verdade, já temos um no título. Embora eu vá citar alguns trechos do livro, é mais por encantamento do que por resumo. Por isso, não se preocupe com spoilers. Temos uma lista deles logo no começo:

[lista]

Do que eu ainda vou fazer neste livro:

Ir para um retiro em Campos do Jordão.

Ter o meu mapa astral feito.

Beijar a Professora de Yoga.

Beijar um homem.

Sofrer com o divórcio.

Morrer todas as manhãs e todas as noites durante trezentos e noventa e quatro dias.

Encerrar o luto.

Me arrepender e mergulhar de volta no luto.

Fingir que eu acredito.

Fingir que eu não acredito.

Reescrever este livro pelo resto da minha vida (Ferro, 2018, p. 25-26). 


\section{O vazio}

Um "lugar vazio em que fala a ociosidade de uma fala vazia" (Blanchot, 2005, p. 312). Vazio falante, silêncio comunicador: metáfora que permite pensarmos esse espaço como fundador de significação. "Mas silêncio desejado não para esconder, e sim para expressar num mais alto grau de desprendimento. A experiência não pode ser comunicada se laços de silêncio, de apagamento, de distância não transformam aqueles que ela põe em jogo" (Bataille, 2016, p. 61). É este elemento, o silêncio, que me parece permitir a relação do conceito de fora de Blanchot e da experiência que ele possibilita com a autoficção, não entendendo-a como gênero literário no qual textualmente ocorre uma relação de identidade entre autor, narrador e protagonista, mas uma leitura-além, de entendermos a autoficção tanto em uma perspectiva objetiva, levando em conta a materialidade e discursividade textual, quanto em uma perspectiva subjetiva: lendo a autoficção como construção de uma realidade outra que, apesar de encontrar sua origem em eventos reais, supera-os, deslocando-os na construção de um Eu-Outro que não quer senão superar no tempo do agora aquilo que foi: lembrança, memória, trauma.

Instalado na ficção, o Eu pode se perder no campo do imaginário e do simbólico para representar suas questões por um viés estético de um não lugar. Impõe-se, dessa forma, a realidade do fora sobre a narração da vivência, pois, uma vez potência do negativo, a linguagem literária possibilita uma liberdade fundamentada na negatividade da morte, e não em uma afirmação da vida. Assim, o espaço literário nega o mundo como nega o tempo, porque tenta condensá-los no espaço negativo da linguagem.

Este é o caráter utópico de toda experiência literária, sua faceta mítica: a tentativa de recriar, por meio da imaginação poética, um mundo onde as necessidades materiais não estão mais em questão, em que a única coisa que conta é a liberdade de criar dispendiosamente, de aproximar-se de algo divino - pois se Deus partiu do nada e criou o universo por meio da linguagem, certamente não foi por necessidade (Pinezi, 2015, p. 122).

Do Éder de onde fala, a voz literária, "voz vinda de outro lugar", não remete a um eu pessoal; logo, não busca uma verdade desse sujeito. Ela transgride a si mesma, não se revelando, mas ocultando em seus silêncios e vazios algo que escapa a toda linguagem. Mesmo na escrita de si, essa voz caminha em exílio, sem tempo e sem nome, habitando a zona do indizível, e encontra ali, na intersecção do silêncio com a palavra, a expressão de sua impossibilidade.

A partir dessa aproximação, entenderei aqui a autoficção como texto ficcional no qual se fala sem censura e sem amarras, estruturada como uma ficção, mas uma ficção ambígua na medida em que relaciona o protagonista, por nome ou dados identificadores, ao autor. Assim como na ficção, na autoficção o Eu pode falar de si e dos outros sem segredos, e entregá-los a "um eu variável, polimorfo, e de se afirmar livre finalmente de ideologias literárias aparentemente ultrapassadas. Ela oferece ao escritor a oportunidade de, a partir de sua vida e da sua ficcionalização, ser ao mesmo tempo ele mesmo e um outro" (Hubier, 2003, p. 125, tradução nossa), ou, como queria o pai do silogismo, Serge Doubrovsky (2007, p. 64, tradução nossa), ser "a tentativa de recuperar, de recriar, refazer em um texto, em um ato de escrita, as experiências de sua própria vida, que não são de modo algum uma reprodução, uma fotografia... É literalmente e literariamente uma reinvenção". Ou ainda: "A autoficção é como um sonho. Um sonho que não é a vida, um livro não é a vida [...] Em nossa apreensão da realidade, existe sempre uma parte de ficção" (Doubrovsky, 2014, s./p., tradução nossa).

O mérito da relação de identidade entre o Eu da ficção e seu autor consiste no carácter ambíguo que fornece à leitura. Essa ambiguidade nasce tanto da friç̧ão textualmente estabelecida entre ficção e realidade como de ocasiões que podem alimentar o jogo proposto na autoficção, como performances do autor, exposição dele em redes sociais e na imprensa, ou, como é o caso de $O$ pai da menina morta, a gestação da ficção a partir de uma experiência real. 


\section{Eu}

Quando pequeno, eu só olhava nos olhos do meu pai quando os nossos olhares se cruzavam, sem querer, pelo retrovisor enquanto ele dirigia.

\section{O pai}

Tiago Ferro nasceu em 1976. A ficha catalográfica e a orelha do livro informam isso.

Em março de 2016, sua filha morreu devido a uma inflamação no miocárdio, consequência de um tipo agressivo de gripe. Ela tinha oito anos.

Em 2018 ele publicou seu primeiro romance.

Minha leitura não parte, apenas, do eu fragmentado e multifacetado que surge no texto, elemento de ambiguidade ali, mas do fato de que na autoficção, sendo fiçção, opera-se o jogo de toda Literatura: o trânsito de experiências e sensações em movimento circular e, por isso, sempre metalinguístico. A experiência deslocada no fora, espaço literário, que é experimentado pelo leitor por meio da linguagem, uma "experiência interior", isto é, "os estados de êxtase, de arrebatamento ou ao menos de emoção meditada" (Bataille, 2016, p. 33), desejo de alteridade, do Outro, de ser outro, de sentir no outro, de ser além. Ékstasis: sair de si. Transcender. Assim, vivenciar a experiência literária é entrar em contato direto com algo latente em toda a humanidade, o contato com o primitivo. Como escreve Bataille (2016, p. 34) em A experiência interior: "A experiência é a colocação em questão (à prova), na febre e na angústia, daquilo que um homem sabe do fato de ser".

No caso especial da autoficção, essa experiência deslocada no fora provém da experiência do próprio autor, o que me parece promover também um deslocamento de afeto na relação autor-leitor. A relação entre afeto-escrita-leitura se constrói de infinitos sentidos e modos, dadas as possibilidades de experiência com as sensações que os afetos possibilitam, intensificando o papel provocador da ficção, isto é: expressar, sob pena de nunca representar, o agora, e fixá-lo no tempo da narrativa. Rompendo, assim, com os paradigmas tradicionais da representação, a autoficção insere o sujeito em outro nível de representação calcada na autoconsciência e suas experiências de sentido.

Nesse sentido, penso na autoficção enquanto escrita que, sendo ficção, penetra na zona nebulosa do espaço ficcional e, concomitantemente, se prende a esta realidade com o firme e forte nó criado pela presença identitária do autor, que, falsa ou não, evoca uma realidade referencial via afeto nas relações estabelecidas pelo leitor, ou seja, a força do testemunho da experiência própria e/ou a ousadia de brincar com a própria morte. Serge Doubrovsky (2007, p. 54, tradução nossa) já afirmou:

O propósito da minha escrita é mais perverso: eu quero que o leitor se identifique comigo, que a escrita seja, como Rousseau queria, não uma forma de absolvição - para mim, não há nenhum Deus perante o qual eu deva me apresentar com o meu livro mas uma forma de partilha; quero que o leitor, se fui bem-sucedido em meu livro, possa compartilhar comigo o que eu próprio vivi.

De fato, qualquer busca de relações de referencialidade nas narrativas resultam infrutíferas, justamente porque o que mais parece interessar na autoficção não é o antes, mas o agora, não o que o autor viveu de fato, mas o que a narrativa constrói de presente na ficção. É a construção desse espaço-fora que permite a construção de si em um Outro-Eu, que se comunica com a nossa referencialidade por meio de um horizonte de expectativas já alterado pela ambiguidade do texto. Nada é certo, nada é fixo. Estamos no domínio do que está sempre por-ser. Nada foi ainda. Tudo está sendo.

Serge Doubrovsky morreu um ano depois, em março de 2017, aos 88 anos.

\section{A menina morta}

"A Minha Filha morreu no dia 26 de abril de 2016" (Ferro, 2018, p. 9).

Em um primeiro momento, o leitor pode acreditar estar diante de um inventário do luto e da saudade. Mas não. O romance não é linear: a fragmentação vai ser representada de várias formas, 
que vão desde a estrutura do texto - pequenos fragmentos de texto com título entre colchetes, como [eu], [sábado], [cinzas], [lista] - até a forma como o protagonista anônimo tenta dar sentido não a uma experiência, mas ao mundo depois dela. Como escreveu Doubrovsky (2011, p. 26, tradução nossa), "[a] escrita autoficcional abole a estrutura narrativa linear" e, por meio de quebras e espaços vazios, "a escrita tenta traduzir a fragmentação, a quebra do eu, a impossibilidade de encontrá-lo numa bela unidade harmoniosa. Nesse surgimento inesperado de palavras e de pensamentos desconexos revela-se uma alteridade fundamental do sujeito ao longo do tempo". Há, entretanto, um traço que atravessa toda a obra e acaba por dar algum sentido a essa apoteose empírica do narrador: o silêncio imposto e que se impõe à narrativa em todo o romance, presente não apenas na voz que se calou, mas, principalmente, na voz que não consegue dizer.

O primeiro fragmento, [eu], autodescreve fisicamente o autor-narrador, com um ou outro traço de personalidade, inclusive dizendo sua idade: 41 anos. Esse narrador autodiegético não permanece na narrativa. Ele intercala com outras vozes impessoais e em $3^{a}$ pessoa, despedaçando também qualquer laço pactual estável: daí a negativa de Ferro de entender seu romance como autoficcional. ${ }^{1}$ Há ali uma série de choques entre pessoas e tempos de um Eu que recusa ser O Pai da Menina Morta. O choque entre esses dois Eus (o de antes e o de agora) concretiza uma narrativa de delírio na qual se percebe a tentativa de materializar o desejo de seguir adiante com uma parte faltante. Para tanto, o escritor lança mão de uma série de recursos que colaboram para uma escrita lacunar e simbólica que dá forma e contorno a esse ser amorfo representado no protagonista, que busca na memória do passado e no confronto com o presente a revalidação da vida. Busca-se, portanto, um sentido onde sentido não há. Não se trata de oferecer ao leitor uma resposta, uma história ou uma anestesia. Trata-se antes de construir, por meio da narrativa, um sentido que não existe para o evento, pois "não se trata de descobrir, mas de inventar, não em todos os detalhes, mas em seus rastros: [o sentido] está por construir" (Doubrovsky, 1988, p. 77, tradução nossa). A autoficção "destoa da autobiografia justamente por querer evidenciar o processo que está correndo, não que já ocorreu. Daí o tempo fragmentado, misto de memória e observação, de real e virtual" (Gasparini, 2004, p. 30, tradução nossa).

No segundo fragmento, [sábado], o protagonista vai ao cinema com a esposa e vê, no caminho, um livro em destaque na vitrine da Fnac. Ele está com o dedinho do pé machucado. E Lina Balbuena é a única personagem nomeada. Os outros são marcados por iniciais, ou chamados como a "Minha Filha". O filme acaba, eles saem, jogam fora o copo de refrigerante e ele reclama das cadeiras do cinema. Não sabemos em que tempo diegético estamos, mas sabemos que ele também não é linear porque, ali, ainda não nasceu nenhuma das duas filhas do casal.

Também não sabemos a qual filme viram. Sabemos ser do Godard e que sua narrativa também é fragmentada. Mas o título do livro apenas observado na vitrine é citado: A idade viril, de Michel Leiris (1901-1990), obra igualmente fragmentada e autobiográfica que funda o que Leiris chamou de "etnologia do eu". Percebe-se já como a intertextualidade será fator importante na construção do sentido e serve de fundamento para a ambiguidade que a autoficção instaura. Esses dois fragmentos também já evidenciam outras características que serão frequentes em tema e estrutura ao longo do romance: a coexistência do essencial e do efêmero, a fragmentação, o não conhecimento pleno das coisas e a dúvida, as informações irrelevantes sendo ditas enquanto as que julgamos essenciais sendo caladas. Todas essas são, no terceiro fragmento do romance, sintetizadas de forma poético-trágica, como será o restante das páginas:

[quinta-feira]

Formolização. Você vai querer?

For-mo-li-za-ção (Ferro, 2018, p. 10).

\footnotetext{
${ }^{1}$ Em entrevista a Maurício Meireles da Folha de S.Paulo, Ferro rejeita o rótulo de autoficção e afirma que o narrador vive situações que não são reais e, por isso, não são suas. "O que temos em comum é a perda da filha. Busquei investigar na forma literária essa ausência, mas não acho que meu livro faça parte do gênero" (apud Meireles, 2018, s/p).
} 
O estado de não ação do protagonista diante da morte da filha move a narrativa na medida em que ele busca uma nova forma de se adequar ao mundo e à vida sem a pessoa amada. $\mathrm{O}$ silêncio e essa não ação marcam a experiência do luto por meio da incapacidade de registro da experiência. Daí a multiplicidade de formas e vozes narrativas: a mudança de vozes verbais, de tempos diegéticos, a friç̧ões entre realidade e ficção colaboram para que o sentido seja expresso, não por uma narrativa lógica, linear e objetiva, mas por fragmentos que evidenciam como o vazio se manifesta no sujeito, ideia representada na eficaz metáfora do feixe: a um "Euprimeiro", outras vozes são incorporadas como em um feixe de gravetos. Por exemplo, a dor que sentirá o apresentador do telejornal ao noticiar a morte da menina, bem como a dor do motorista que o leva para casa naquela noite, serão incorporadas à narrativa: "O motorista e o apresentador, alguns segundos antes de dormir, vão pensar no pai da criança de oito anos, de classe média paulistana, com acesso às melhores escolas e hospitais, vítima de gripe. Coitado. Que Deus tenha piedade dele. Esse se fodeu" (Ferro, 2018, p. 14-15). Ou ainda, a experiência dos avós, que se perderam de uma filha quando pequena, e de outros pais cujos filhos morreram: Eric Clapton, Gilberto Gil, Carlos Drummond de Andrade.

Outro exemplo desse deslocamento e incorporação de vozes são os momentos em que temos uma (falsa?) terceira pessoa, nos quais o Eu é transfigurado em objeto de análise tanto pelo "ele" que se impõe como nas situações nas quais é inserido, como mostra o sexto fragmento, "[terceira pessoa do singular. masculino. cena 1: afasia. derrame]" (Ferro, 2018, p. 11). O distanciamento e o deslocamento são marcados pela transfiguração do eu, ora em uma terceira pessoa que, embora se mantenha masculina, se ergue enquanto objeto dramatizado, ora como experiência do outro como necessária ao indivíduo para experimentar sua dor na medida que esse eu se desloca para fora de si. "Em outros termos, só se atingem estados de êxtase ou de arrebatamento dramatizando a existência em geral" (Bataille, 2016, p. 41). Sem a dramatização, viveríamos presos em nós mesmos, isolados e apertados. Não saberíamos rir, diz Bataille, e desejar nunca morrer.

Assim como o silêncio privativo será frequentemente imposto, a voz impudica também estará presente na aproximação entre sexo e morte não apenas ao referenciar e citar Bataille, mas também no que mais se aproxima de uma imagem do personagem que temos: esse homem de 41 anos que, após a morte da filha, começa a fazer yoga e terapia e se envolve tanto com sua professora de yoga quanto com seu terapeuta. A yoga, inclusive, assim como o sexo e as drogas, são imagens assumidas na narrativa que ilustram o deslocamento para fora de si, o êxtase, o gozo: "Desaparecer No Outro Infinito" (Ferro, 2018, p. 88). O erotismo, como queria Bataille (1987, p. 10), "é aprovação da vida até na morte". O corpo se torna única fonte possível de prazer justamente porque se mostra como única realidade empírica, única fonte de experiência. Tudo passa pelo corpo, estamos presos a eles como condenados. Ele, então, experimenta. "Um orgasmo longo me arranca daquele quarto, deste mundo, do tempo" (Ferro, 2018, p. 70). Nesse exemplo, é interessante o efeito do uso dos três pronomes demonstrativos (daquele, deste, do), que bem exemplifica o cruzamento tempo-espacial do enunciador. Longe de causar incômodo, o jogo se mostra criativo enquanto construção intertextual, que também colabora para aquele deslocamento: temos também ali Freud, Hermann Kafka, Bataille, Leiris, Boris Fausto. Tudo é brecha para sair desse eu rejeitado do Pai da Menina Morta. Tudo é caminho para o exílio, o deserto. Escreve ele:

A lâmina faz uma curva errada e o pescoço começa a sangrar. Arde. Ele coloca a mão direita na água da torneira. Ele coloca a mão direita no deserto do Saara, na merda do cachorro. Ele olha para a mão esquerda e não entende. Ele se olha no espelho e vê um sonho. Ele tenta falar, mas as palavras. Ele quer pedir água. Ele quer chamar a mulher. Ele pensa em árvores que crescem se enrolando no tronco de outras árvores. Ele não consegue abrir a porta do banheiro. Está trancada? Não. Ele antes precisa conseguir falar a palavra maçaneta (Ferro, 2018, p. 11, grifo nosso).

A representação desse Eu só é possível assim, por fragmentos e reflexos dele e de outros. Por isso o Eu se desloca, deixa de ser a voz de Tiago Ferro que perdeu sua filha em 2016 para ser a voz do Pai da Menina Morta, ausente de tempo e de espaço. "Um dia essa tristeza vai virar outra coisa. Uma coisa sem nome. Uma coisa" (Ferro, 2018, p. 44), talvez uma coisa que nomeie 
também o quarto que ficou e que sua Outra Filha não deixa ninguém arrumar: "Ela diz que não é bagunça. É outra coisa. Mas ela ainda não sabe o nome" (Ferro, 2018, p. 73). A tentativa de representação da experiência funda-se, paradoxalmente, em sua impossibilidade de dizer, representada nos silêncios e nos vazios, como nos fragmentos intitulados [lista]. Elas são, por exemplo: "De títulos para este livro" (p. 18), "Do que eu ainda vou fazer neste livro" (p. 25), de sonhos, planos, dúvidas bobas. Mas são também "Do que não vai dar pra fazer neste livro: Trazer a Minha Filha de volta à vida" (p. 35). Ou ainda:

De medos:

Formolização.

Miocardite.

Ninguém aparecer.

Enterrar a Minha Outra Filha (Ferro, 2018, p. 82).

Percebe-se que o trauma do passado é paralelo ao medo do futuro, que agora se torna, antes de ser, um perigo. Esse jogo entre os três tempos, característico da autoficção, se mostra também nostálgico ao projetar as possibilidades de futuro que se encerram.

Não deu tempo de levar a Minha Filha para Paris, para as praias no Nordeste, para mergulhar em Bonito. Não deu tempo de tomar com ela um copo de cerveja e uma taça de vinho. Não deu tempo de ouvir com ela sobre sexo, menstruação, camisinha e Aids. Não deu tempo de discutir o Dom Casmurro. [...] Não deu tempo de ela andar ao meu lado no banco da frente do carro. Não deu tempo de parabenizá-la por ter entrando na História, na Arquitetura, na Medicina, por ter decidido não fazer faculdade e ter largado tudo para ir morar em uma comunidade em Piracanga. [...] O que realmente me dá medo é o que não deu tempo para ela pensar em fazer comigo. Os sonhos dela. Ou ainda, o que ela nem chegou a sonhar. Esses se tornaram insondáveis. Um mundo que eu não posso acessar. Fechado no cérebro já desligado dela (Ferro, 2018, p. 108-109).

A saudade do futuro, como podemos chamar, insere fatalmente o sujeito na impossibilidade das coisas, de representar não apenas a própria realidade que o cerca e que se apresenta inapreensível, mas também aquela outra que agora se ergue diante dele: os sonhos da filha, mundo inacessível, história interrompida. O fragmento anterior ilustra bem esse movimento que me parece justo: relacionar os vazios e ausências da narrativa à experiência real do autor que a origina. Esse eu que é fragilmente desenhado no romance surge, principalmente, nos fragmentos intitulados [eu] e naqueles que recebem nome de dias da semana, como entradas em um diário. Em um deles, [sexta-feira], ele diz:

Eu não quero ser O Pai da Menina Morta. Eu sempre serei O Pai da Menina Morta. Eu simplesmente aceito a dor aguda na ausência. No vazio. Nós também somos feitos de espaços em branco. Nosso corpo não é uma massa densa. É preciso lembrar disso. Há centenas de cavidades, buracos, esconderijos, zonas mortas, terrenos baldios. A medicina nunca procurou curar a dor dilacerante nesses não lugares da massa corpórea. As drogas não agem no vazio. Eu sinto profundamente cada um desses espaços. São abismos internos. É preciso cuidado para não se perder (Ferro, 2018, p. 17).

Mais uma vez se percebe como esse sujeito desnorteado mistura tempos e pessoas assim como mistura ficção, sonho e realidade. Ele experimenta a vida a partir da busca em sair de si, deixar de ser o que é para ser outro. Daí, talvez, a presença da meditação, das drogas, do sexo, elementos que também dialogam com Bataille e Blanchot. A ficção preencherá esses vazios e tentará dar sentido à experiência, pois, como trauma, ela desfocou a realidade desse que agora é chamado de O Pai da Menina Morta. Como ele mesmo se pergunta, e se "realidade e sonho forem categorias falsas para nos distrair da verdade de que a vida é apenas uma gravação?" (Ferro, 2018, p. 68). Seríamos, portanto, espectadores de nossas vidas, e não sujeitos, leitura justificada também pela presença intertextual do filme Matrix. "Quem morre em um sonho nunca mais acorda" (Ferro, 2018, p. 12), ele cita. Assim como Neo, o Pai da Menina Morta é o escolhido e precisa lidar com essa realidade que lhe foi imposta. A meu ver, como o efeito conferido pelo metateatro em uma representação cênica, a autofiç̧ão questiona não a presença do que é, de fato, referencial no texto 
ficcional, mas em que medida não transformamos a própria realidade em ficção, permitindo, como faz Morpheus ao Escolhido, questionar: "O que é real? Como você o define?".

Diante dessas perguntas, questiona-se o real ao mesmo tempo em que se mescla ilusão e realidade, como este outro fragmento, [segunda-feira], ilustra:

Entro numa rua contramão. Vou devagar até o fim em vez de dar ré. Atropelo uma idosa com seu neto. É uma cena grotesca, mas linda. Poder tocar a carne viva-morta. [...] De tanto exercitar o olho deslocado, o filósofo francês Althusser teve um surto psicótico e estrangulou a própria mulher. Foi em 1980. [...] O Althusser uma vez perguntou para si mesmo se Napoleão realmente havia existido da forma como o conhecemos. Ele não era mais capaz de tocar a realidade (Ferro, 2018, p. 27).

Relacionando essa incapacidade de tocar o real a uma leitura psicanalítica, a experiência autoficcional seria, portanto, uma tentativa de "distinguir qual parte da realidade é 'transfuncionalizada' pela fantasia, de forma que, apesar de ser parte da realidade, seja percebida num modo ficcional" (Žižek, 2011, p. 36), como se "o que está colocado no papel fosse traumático demais para ser dito face a face" (Žižek, 2011, p. 37). A ficção como fruto desse "olho deslocado". Aproximar o viés psicanalítico, aqui representado pela perspectiva lacaniana de Slavoj Žižek (2011, p. 36), e a autoficção me parece viável justamente porque "muito mais difícil do que denunciar ou desmascarar como ficção (o que parece ser) a realidade é reconhecer a parte da ficção na realidade 'real'". É reconhecer que "o real precisa ser ficcionalizado para ser pensado" (Rancière, 2005, p. 58), principalmente quando esse real é marcado por um encontro faltoso, pelo trauma. "Sim, é preciso encontrar sentido. Criação. Localizar quem passou pelo mesmo tipo de sofrimento e estudar suas vidas detalhadamente. Dia por dia, hora a hora. Cada ação, pensamento, emoção e desejo. Procurar nos sonhos o inconsciente, no riso os segredos" (Ferro, 2018, p. 167). Daí sempre existir algo que escapa à linguagem, algo preso ao riso ou ao silêncio. Mas escolher enfrentá-lo, dia a dia. O real. Como escreve Žižek (2011, p. 37): “a verdadeira escolha com relação ao trauma histórico não está entre lembrar-se ou esquecer-se dele [...] É necessário então aceitar o paradoxo de que, para realmente esquecer um acontecimento, precisamos primeiramente criar a força para lembrá-lo". Eis o paradoxo trágico do Pai: "Quando me esqueço da dor, eu me afasto da Minha Filha” (Ferro, 2018, p. 70).

Entretanto, a presença de Freud, Bataille e Drummond são apenas rastros, pegadas de sentido que o narrador vai deixando enquanto desenrola uma teia intertextual. "Esqueçam a psicanálise. Eles jamais vão entender a anatomia do sofrimento enquanto insistirem nas fórmulas prontas de Viena ou Paris" (Ferro, 2018, p. 155). As nuances do jogo proposto vão, então, surgindo aos poucos, plantando ora a dúvida, ora certa clareza ao leitor que, também lúdico, aceita o jogo. Tudo é ambíguo, mesmo os fragmentos estruturados como verbetes de dicionário, gênero geralmente tão exato, ou os que apresentam apenas fotografias, como os fragmentos [1961], [1986] e [1978], respectivamente a fotografia de Yuri Gagarin, do Diego Maradona no drible que decidiu a Copa e de um bebê, que, seguindo a lógica da relação entre as imagens e os anos dos títulos, trata-se do próprio autor e de mais um recurso de ambiguidade na narrativa.

Vale a lembrança de que presença de textos não verbais nos fragmentos reforça o caráter intergenérico do romance, que incorpora também e-mails, obituários, playlist, procedimento de busca na internet, de envio de mensagem pelo Facebook, mensagens de WhatsApp, formulários, receita culinária e até mesmo configurações em HTML. Por sua vez, essa ampla intergenerecidade é outro traço da ambientação ambígua, da narrativa híbrida, como "algo preso entre dois mundos" (Ferro, 2018, p. 65), um entre-espaço, lugar de negação e ausência que confirma, estruturalmente, o hibridismo entre realidade e ficção, entre os gêneros textuais/literários, entre a primeira e a terceira pessoa etc. Parece-me que isso se justifica pela narrativa ter nascido da experiência: uma vez que o que está em xeque são as sensações que movimentaram essa experiência, a narrativa nasce de uma espécie de teia memorialística que permite o desenrolar sem medida da trama de tempos e espaços. O hibridismo e a fragmentação refletem também a própria descentralização do protagonista e do mundo que o cerca. Mergulhado no vazio, ele escolhe se formar a partir daquele ponto zero, daquele deserto, o fora. Entretanto, assim como o fora nasce da contraposição entre criar e destruir, aqui também a formação do sujeito se dá em choque 
constante com alguém que ele rejeita ser, preenchido de falta e vazio, pois "a memória vive te enganando. Na gosma do meu cérebro-fiç̧ão, eu já não tenho certeza se eu não sou Ela" (Ferro, 2018, p. 159). Daí a noção de trauma me parecer esclarecedora.

De fato, aparentemente, o romance escapa à uma autofiç̧ão "tradicional" na medida em que o narrador se afasta de uma pessoalidade identitária, porém ele faz isso com uma narrativa que, queira ou não, aproxima a experiência ficcional da sua experiência referencial. É essa espiral narrativa que me permite entender, portanto, o romance de Tiago Ferro como uma paródia da autoficção, pois se utiliza de material abertamente autobiográfico para, num jogo meta e intertextual, criar uma narrativa múltipla e incrivelmente sensível à experiência da perda e do luto: há, sabemos, "um tênue fio, mas ainda um fio, [que] liga o apreendido ao eu" (Bataille, 2016, p. 35). A autoficção no romance, e talvez isto soe mais subjetivo do que eu pretenda, é empregada enquanto gênese, base para que uma ficção poética se estruture e se desmorone sobre a mesma base na qual se sustentou. De duas maneiras, assim, o romance é metatextual: primeiro, a metalinguagem é apresentada textualmente para encenar o processo de escrita - como os fragmentos [whatsapp], "Querido, o pessoal da editora adorou a amostra que você mandou. Mas eles querem mais. Mais verdade. Mais benzina. Mais sangue" (Ferro, 2018, p. 90); "Acha mesmo que essa mistura de sexo e morte funciona?" (Ferro, 2018, p. 123), e [leitor amigo], “Você não acha que em algum ponto será preciso oferecer uma saída? Um pouco de luz, talvez?" (Ferro, 2018, p. 147).

Em segundo, metalinguístico não por ser uma autoficção, mas por ser uma (auto)ficção que parodia a autoficção por meio de pistas, muitas vezes falsas, de uma identidade referencial. Ao empreender esse ousado projeto, a narrativa coloca em questionamento conceitos de ausência, autenticidade, realidade e memória. Daí o valor semântico do silêncio e da síntese, presente tanto nos vazios como no próprio texto enquanto tentativa de captar o que se deseja, como mostram os fragmentos intitulados [silêncio], como este, constituído de apenas uma palavra: "Filha?" (Ferro, 2018, p. 21). O silêncio responde, induz, significa. O silêncio que segue o chamamento conduz o leitor pelo corredor árido da solidão e do luto, sem que as suas sensações sejam descritas ou mencionadas ou a referencialidade seja "confirmada". Existem apenas a possibilidade e o silêncio diante do vocativo, pois aquela que é chamada não existe mais enquanto resposta, presença, espaço. Corpo. O silêncio dá voz ao ausente, presentifica-o. Ele é, então, o personagem central. Mas não faço com isso nenhuma descoberta. A dedicatória, "Aos que restaram", já indica que alguém partiu, que existe uma ausência ali que é espelhada nos vazios físicos, emocionais e existenciais do Pai da Menina Morta.

Nesse jogo, o romance também questiona, esteticamente, as categorias de autor, de verdade e de representação. A narrativa entrelaça duas possibilidades (ou mais) em uma única voz, fazendo com que as perspectivas narrativas se cruzem, como mostra o fragmento [quinta-feira]:

A igreja está lotada. [...] A missa é para a Minha Filha e também para celebrar as bodas de um casal, que vai até o padre receber uma benção ou algo assim. Eles não se abalam por dividir a celebração com um momento tão triste. O padre fala sobre a inteireza da vida ali representada. [...] Nós decidimos que não seremos uma família triste. De onde eu tirei essa autoridade? Ninguém sabe. Você é um impostor. Nunca se esqueça disso. [...] Um ano depois não haverá uma nova missa. Minha identidade foi revelada. Não se engana o inimigo duas vezes (Ferro, 2018, p. 92-93).

Ao mesmo tempo que explora o ficcional, apontando pensamentos do padre e do casal, por exemplo, o fragmento também soa autobiográfico, como confirmam textos publicados pelo autor em suas redes sociais e notícias que circularam no meio editorial. Uma postagem de Tiago Ferro no dia 6 de abril de 2016 no Facebook, dia da missa de sétimo dia de sua filha Manu, diz: "Eu sempre achei que missas eram um prolongamento desnecessário da dor. [...] Infelizmente nos é vedada à razão a compreensão completa do tempo, que é eterno. [...] Nós decidimos que não seremos uma família triste".

A partir desses cruzamentos, o narrador finaliza o romance em um capítulo longo, diferente dos pequenos fragmentos que nos levaram até o fim. Ele mostra, em uma apoteose verborrágica de vozes, um possível sentido ao sem sentido a essa que é mais uma entre as "centenas de bilhões de pequenas dores, tragédias particulares, mudas, os lutos todos [...]" (Ferro, 2018, p. 153). 
O Clapton só encontra a paz no sono. Jamais nos sonhos. Sempre o mesmo pesadelo: ele sai do banho e o filho desapareceu, ele o procura por toda a casa e quando acorda leva três segundos para se lembrar que o garoto havia morrido. Memória-Dor. Estamos todos muito cansados. [...] No Rio de Janeiro, Carlos está morrendo sem saber. A dor vai durar exatos doze dias. [...] O amor deveria garantir que as duas partes desaparecessem juntas, ou no máximo em um intervalo de doze segundos (Ferro, 2018, p. 152).

Ao falar de Clapton e Drummond, não sabemos onde começa e termina a experiência de cada um, e não precisamos saber: "A dor é a mesma para todos" (Ferro, 2018, p. 155). E é preciso, ele sabe, tocá-la, "dar forma à dor, uma dor sem nome e as notas musicais evaporando sem parar" (Ferro, 2018, p. 153). Aqui, mais uma vez a possível efemeridade da própria escrita, o vazio da representação, do indizível. A singularidade da narrativa de Ferro está na coragem de uma voz que ousa nascer no vazio da escrita, ciente que ela voltará inevitavelmente ao vazio que a gerou.

\section{O pai da menina morta}

Todas as noites pedindo para morrer, O Pai da Menina Morta se apresenta voluntariamente em uma clínica psiquiátrica. Ali o encontramos nas últimas páginas. Incrivelmente irônico, ele sabe de nossa presença ali. "Vocês não encontraram as respostas, mas as regras do jogo ficaram mais claras" (Ferro, 2018, p. 156). Ao mesmo tempo, soa mais confuso que o leitor, denuncia que escritores são impostores, que livros são "experiências de segunda mão". Mas quem diz? Como Foucault lendo Beckett, ele pergunta: “Quem fala aqui afinal? Quem é Eu? O corpo dilacerado pelo ferro retorcido do que um dia foi um automóvel. [...] Ninguém vai me entender. Ninguém quer saber. Quantos nós somos afinal?" (Ferro, 2018, p. 157). O tom paródico da narrativa nasce da estrutura que entrelaça uma possível autoficção autêntica - isto é, a história/experiência de um pai que perdeu a filha - a outra que é, textualmente, ironizada ao ser deslocada para a ficção, que acaba por ser tornar, ela também, um dos recursos para esse efeito paródico. Ele mesmo sabe: "Eu sou Vários? A multidão que me habita, os tempos históricos e todo o ópio que corta os meus desejos de reconciliação" (Ferro, 2018, p. 159). Nessa multidão, Tiago Ferro é sem dúvida uma parte. Talvez aquela voz que pergunta: "Quem são esses Eus todos querendo que a cama nos engula definitivamente?" (p. 160). Talvez, esses outros Eus. "Quem sou esse Você?”, ele pergunta. Um Eu nu. Liga-se, assim, a experiência ao fora, ao deslocamento.

A experiência tem por função retirar o sujeito de si mesmo, de fazer com que ele não seja mais o mesmo. A experiência revela e oculta, tem espaços de luz e de sombras. A experiência não é apreendida para ser repetida, simplesmente, passivamente transmitida, ela acontece para migrar, recriar, potencializar outras vivências, outras diferenças. Há uma constante negociação para que ela exista, não se isole. Aprender com a experiência é, sobretudo fazer daquilo que não somos, mas poderíamos ser, parte integrante de nosso mundo. A experiência é mais vidente que evidente, criadora que reprodutora (Lopes, 2002, p. 253-254).

Transformada em (auto)ficção, a experiência é deslocada também a outra temporalidade, não mais sujeita ao tempo. Presa na repetição, looping daquele momento, o Pai da Menina Morta vai aos poucos tomando consciência e descobrindo que está pronto. "Ele conta com o Autor Destes Fragmentos para narrar cada ato dele de forma idêntica ao escrito pelo Bataille. Ele sugere ao Autor Destes Fragmentos que dê copy/paste no texto original para que tudo saia perfeito" (Ferro, 2018, p. 117).

A partir dessa metatextualidade, instaura-se o caráter paródico não apenas na estrutura narrativa, mas também no protagonista, paródia encarnada, como o chamaria Bataille. Como o próprio narrador diz, citando ainda Bataille, "o mundo é puramente paródico, isto é, cada coisa que se vê é a paródia de uma outra ou ainda a mesma coisa sob uma forma enganadora" (Ferro, 2018, p. 141). Ambíguo, o mundo agora é outro. Nessa experiência do fora, na realidade literária, liberdade é sobrenome daquele Eu. Parece-me que o efeito paródico ao qual me refiro intensifica o jogo das possibilidades com a autoficção: nela temos a fala do silêncio no auto, a tentativa do dizer na ficção. 
Diante do deserto do real, o sujeito só pode voltar-se a si mesmo, ao seu corpo. Encarar-se no espelho e sentir compaixão pelo que vê, amor, compreensão e sobretudo aceitação. $O$ desejo incontrolável de ser outro. Maquilar aqui e ali uma máscara, um jeito diferente de andar, de ser. A autoficção é a reflexão estética sobre esta inconstante busca do pensamento humano: a verdade sobre si. O enigma esfíngico, "conhece-te a ti mesmo", revela ao humano o absurdo da existência. A autoficção é, assim, uma proposta de mito pessoal. Uma metáfora para essa metonímia que é o Eu. Um outro real diante deste.

\section{Hoje}

Hoje é aniversário de meu pai.

Mandei uma mensagem assim que acordei. Logo depois, recebi um vídeo de meu pai conversando em uma roda de amigos. Observo seus jeitos, seus gestos. Nunca antes tinha visto-o assim, analisável. Ele ri, conta piada e uma história que não sei se verdadeira ou não. E num assombro me vejo ali, o mesmo sorriso, o mesmo movimento de mãos. "Nossa! É você velho, né?", alguém me disse. E percebo: há algo nesse rosto velho que encaro no espelho que remete imediatamente ao primeiro homem que conheci, aquele que me olhava pelo retrovisor enquanto dirigia. Algo nele me inspira Adão, passado, respeito. Gratidão. Dignidade. E então lembro de coisas que não lembro com frequência: o som do riso dele, as mãos para trás ao falar, o ajeitar do bigode. Ele sorri com facilidade e isso é lindo. Vejo e revejo o vídeo e percebo o quanto ele é engraçado naturalmente, o quanto ele incorpora nítidas mentiras e anedotas enquanto responde a uma pergunta trivial, o quanto ele mistura verdade e ficção na sua fala, com ar de grande sábio, pajé. Híbrido. Ar de quem muito experimentou. Percebo o quanto ele é autoficcional.

Hoje, um 16 de junho, percebi isso.

Só hoje. Um Bloomsday.

\section{Referências}

AGAMBEN, Giogio (2005). Infância e história: destruição da experiência e origem da história. Tradução de Henrique Burigo. Belo Horizonte: Ed. UFMG.

BATAILLE, Georges (2016). A experiência interior: seguida de Método de Meditação e Postscriptum 1953: Suma ateológica. Tradução de Fernando Scheibe. Belo Horizonte: Autêntica. v. 1.

BENJAMIN, Walter (1996). Experiência e pobreza. In: BENJAMIN, Walter. Magia e técnica, arte e politica: ensaios sobre literatura e história da cultura. Tradução de Sérgio Paulo Rouanet. São Paulo: Brasiliense. p. 114-119. (Obras escolhidas, v. 1).

BENJAMIN, Walter (1996). O narrador. Considerações sobre a obra de Nikolai Leskov. In: BENJAMIN, Walter. Magia e técnica, arte e política: ensaios sobre literatura e história da cultura. Tradução de Sérgio Paulo Rouanet. São Paulo: Brasiliense. p. 197-221. (Obras escolhidas, v. 1).

BLANCHOT, Maurice (2011). A parte do fogo. Tradução de Ana Maria Scherer. Rio de Janeiro: Rocco.

BLANCHOT, Maurice (2005). O livro por vir. Tradução de Leyla Perrone-Moisés. São Paulo: Martins Fontes.

DOUBROVSKY, Serge (1988). Autobiographiques: de Corneille à Sartre. Paris: Presses Universitaires de France.

DOUBROVSKY, Serge (2007). Les points sur ler “i”. In: JEANNELLE, Jean-Louis.; VIOLLET, Catherine. (Dir.). Genèse et autofiction. Louvain-la-Neuve: Academia. p. 54-65.

DOUBROVSKY, Serge (2011). C'est fini. Entretien réalisé par Isabelle Grell. In: FOREST, Philippe (Dir.). La Nouvelle Revue Française, Paris, Gallimard, n. 598, Je \& Moi, oct.

DOUBROVSKY, Serge (2014). Serge Doubrovsky, inventeur de l'autofiction: "Un individu, ce n'est pas que beau à voir". Entrevista concedida a Nathalie Crom. Télérama, Paris, 29 ago. 2014. Disponível em: https:// bit.ly/2JJkvQ9. Acesso em: 20 jun. 2018. 
FERRO, Tiago (2018). O pai da menina morta. São Paulo: Todavia.

FERRO, Tiago (2016). Postagem em página pessoal no Facebook, 6 abr. Disponível em: https:// bit.ly/2HqCARv. Acesso em: 25 mar. 2018.

GASPARINI, Philippe (2004). Est-il je? Roman autobiographique et autofiction. Paris: Seuil.

HUBIER, Sébastien (2003). Littératures intimes: les expressions du moi, de l'autobiographie à l'autofiction. Paris: Armand Colin.

KNAUSGÅRD, Karl Ove (2015). Minha luta: a morte do pai. Tradução de Leonardo Pinto Silva. São Paulo: Companhia das Letras.

LEVY, Tatiana Salém (2011). A experiência do fora: Blanchot, Foucault e Deleuze. Rio de Janeiro: Civilização Brasileira.

LOPES, Denilson (2002). Experiência e literatura. In: LOPES, Denilson. O homem que amava rapazes e outros ensaios. Rio de Janeiro: Aeroplano.

MEIRELES, Maurício (2018). Luto inspira $1^{\circ}$ romance de Tiago Ferro. Folha de S. Paulo, São Paulo, Caderno Ilustrada, 14 mar. Disponível em: https:/ / bit.ly/2VIG2zv. Acesso em: 20 jun. 2018.

PINEZI, Gabriel V. R. (2015). A experiência literária de Jack Kerouac: a criação da liberdade, a liberdade da criação. Tese (Doutorado em Letras) - Universidade Estadual de Londrina, Londrina. Disponível em: https:// bit.ly/2HA9C0b. Acesso em: 20 jun. 2018.

RANCIÈRE, Jacques (2005). A partilha do sensível: estética e política. Tradução de Mônica Costa Netto. São Paulo: Editora 34.

WOOD, James (2017). A coisa mais próxima da vida. Tradução de Denise Bottmann. São Paulo: SESI-SP.

ŽIŽEK, Slavoj (2011). Bem-vindo ao deserto do real. Tradução de Paulo Cézar Castanheira. São Paulo: Boitempo. 